\title{
Ecosystem metabolism in a subtropical, seagrass-dominated lagoon
}

\author{
Susan Ziegler*, Ronald Benner \\ Marine Science Institute, University of Texas at Austin, Port Aransas, Texas 78373, USA
}

\begin{abstract}
Measurements of ecosystem gross primary production (GPP) and respiration (R) were made for 2 to 3 consecutive days on 10 occasions from February 1996 through June 1997 in the seagrass-dominated Laguna Madre (Texas, USA). Ecosystem GPP and R were quantified using 3 independent measurements including the open-water technique using dissolved oxygen (DO) and dissolved inorganic carbon (DIC) and the summation of discrete measurements of the water column and benthos. Diel curves of DIC were often influenced by water movement while the impact of water movement on DO was not apparent. This was attributed to the longer turnover time of DIC relative to DO in the water column. The ecosystem GPP and R estimated using the open-water method with DO ranged from 56 to 366 and 103 to $381 \mathrm{mmol} \mathrm{C} \mathrm{m}^{-2} \mathrm{~d}^{-1}$, respectively. The discrete estimates of GPP and $\mathrm{R}$ were usually lower and ranged from 81 to 233 and 54 to $218 \mathrm{mmol} \mathrm{C} \mathrm{m} \mathrm{m}^{-2} \mathrm{~d}^{-1}$, respectively. The results of these 2 approaches indicated that Laguna Madre is a very productive system where GPP and R are nearly balanced. Rates of GPP and R for this system were similar to those measured in other studies of temperate and tropical seagrass systems. Discrete measurements of GPP and R indicated that the water column was net heterotrophic most of the year (annually weighted average $P: R=0.27$ ). Measurements of benthic GPP and R indicated that it was net autotrophic during the entire year (annual P:R $=1.16$ ), suggesting that the benthos was responsible for fueling heterotrophic activity in the water column.
\end{abstract}

KEY WORDS: Ecosystem metabolism - Production · Respiration - Seagrasses

\section{INTRODUCTION}

Rates of primary production in seagrass-dominated estuaries are high and in the range of rates found for salt marshes and coral reefs (Odum 1971). There is a widespread distribution of seagrass communities worldwide and these communities are known to support rich and diverse populations of both autotrophic and heterotrophic organisms. Seagrass communities stabilize bottom sediments and serve as important habitat, including nurseries for many marine species (Larkum et al. 1989, Zieman \& Zieman 1989). Laguna Madre (Texas, USA) is a large seagrass-dominated, shallow lagoon which receives little riverine input or precipitation (Trewartha 1961, Behrens 1966, Critchfield 1974). Despite the lack of inorganic nutrients from rivers this ecosystem is highly productive and has been

\footnotetext{
- Present address: Geophysical Laboratory, Carnegie Institution of Washington, 5251 Broad Branch Rd NW, Washington, DC 20015, USA. E-mail: ziegler@gl.ciw.edu
}

an important source of fish, contributing as much as $50 \%$ of the total annual catch from the Texas coast (Hedgepeth 1967). Seagrass meadows cover approximately $75 \%$ of the total area of Laguna Madre and are thought to be responsible for supporting the high secondary production of this system (Odum \& Wilson 1962, Quammen \& Onuf 1993, Dunton \& Tomasko 1994).

Many studies have addressed the metabolism of the seagrasses within different estuaries, as they are the most visible primary producers in these systems (Patriquin 1973, McRoy 1974, Peduzzi \& Vukovic 1990). In only a few cases have investigators measured the total system metabolism of these systems (Odum \& Hoskin 1958, Nixon \& Oviatt 1972, Murray \& Wetzel 1987). Studies have shown that seagrasses themselves are highly productive, however little is known about how they relate to the total system metabolism. One study conducted in 2 different seagrass communities, Zostera marina and Ruppia maritima meadows, investigated separate components of these systems and 
found that planktonic and benthic microalgae represented as much as $30 \%$ and $14 \%$ of the total system gross primary production (GPP), respectively (Murray \& Wetzel 1987).

Ecosystem metabolism has been estimated for various aquatic systems using a variety of methods. The open-water approach as introduced by Odum (1956) involves the measurement of changes in dissolved oxygen (DO) or dissolved inorganic carbon (DIC) over a diel cycle. Horizontal water advection and the difficulty in estimating the gas exchange of oxygen $\left(\mathrm{O}_{2}\right)$ and carbon dioxide $\left(\mathrm{CO}_{2}\right)$ across the air-water interface are the major drawbacks to the open-water approach. Despite its limitations, the open-water approach has been used successfully in lakes, ponds, streams, rivers, and estuaries (Odum \& Wilson 1962, Kelly et al. 1974, Fontaine \& Ewel 1981, Howarth et al. 1992, D'Avanzo et al. 1996). A related technique, referred to in this paper as the discrete approach. requires the measurement of changes in DO or DIC in discrete samples of the system using enclosures such as bottles and benthic chambers. This approach avoids the problem of water movement and the estimation of gas exchange, but can suffer from other problems. Containment prevents normal current flow and exchange of metabolites which may ultimately affect rates of metabolism. The components measured as part of the discrete approach may not capture all the sources of production or respiration and may underestimate rates of metabolism (Odum \& Hoskin 1958, Verduin 1960, Kemp \& Boynton 1980). In some applications the measurement of separate entities may be important to specific research questions and this benefit could outweigh the potential drawbacks associated with the method.

The results of measurements of ecosystem metabolism, measured using 3 independent approaches, in the Laguna Madre are presented here and represent part of a larger project investigating carbon and nutrient cycling. The purpose of this study was to obtain reliable estimates of ecosystem metabolism for the benthos and water column of a seagrass system, and to determine the significance of these 2 components to total system metabolism. We employed the open-water method, using both DO and DIC, and a discrete method to obtain these measurements over a 16 mo period from February 1996 to June 1997

\section{MATERIALS AND METHODS}

Site description. Laguna Madre, which is separated from the Gulf of Mexico by Padre Island, is the southernmost embayment located along the south Texas coast. It is divided into north and south components, the upper Laguna Madre and lower Laguna Madre, respectively, by $40 \mathrm{~km}$ of sand and mud flats that are infrequently inundated. The Gulf Intracoastal Waterway, a dredged shipping channel, traverses the length of the system, providing a connection between upper and lower Laguna Madre. The lagoon extends $200 \mathrm{~km}$ south from Corpus Christi Bay to the Rio Grande. It is about $12 \mathrm{~km}$ at its widest point, and has an average depth of about $1 \mathrm{~m}$, excluding dredged channels. There is very little freshwater input into this system. Annual precipitation in the region is about 61 to $79 \mathrm{~cm}$ and total freshwater discharge is about $10 \mathrm{~m}^{3} \mathrm{~s}^{-1}$ during a 'normal' year (Trewartha 1961, Behrens 1966, Critchfield 1974). The prevailing SE winds average about $5 \mathrm{~m} \mathrm{~s}^{-1}$ and are responsible for much of the water movement within the system. Tidal range varies between $<10$ and $30 \mathrm{~cm}$, and the tidal excursion is estimated to be about $5 \mathrm{~km}$. Water residence time is estimated to be about 10 to $14 \mathrm{~d}$ within the area between Brazos Santiago Pass and about $15 \mathrm{~km}$ north into the Laguna Madre (G. Ward pers. comm.).

Seagrass meadows cover an area $>700 \mathrm{~km}^{2}$ in Laguna Madre and are thought to be responsible for much of the primary production of the system (Quammen \& Onuf 1993, Dunton \& Tomasko 1994). Our study site was located in a Thalassia testudinum dominated seagrass meadow in the southern portion of lower Laguna Madre. Beds of Syringodium filiforme Kützing and Halodule wrightii as well as drift algal species such as Digenia simplex and Laurencia poitei are also located in lower Laguna Madre (Humm \& Hildebrand 1962, Onuf 1996). The study site was located east of the Gulf Intracoastal Waterway at about $26^{\circ} 10^{\prime} \mathrm{N}$, $97^{\circ} 12^{\prime} \mathrm{W}$ (see Herzka \& Dunton 1996 for map). A total of 10 trips, $5 \mathrm{~d}$ each in length, were made to lower Laguna Madre approximately every 6 to 8 wk from February 1996 to June 1997.

Open-water measurements of system GPP and R. We used the method described by Odum \& Hoskin (1958) and made diel measurements of both DO and DIC. Values are reported as the mean of all daily values determined for each trip with percent mean deviation when $n=2$ and standard deviation when $n=3$. We used the average nighttime rate of change to represent the hourly rate of respiration $(R)$ for the entire day, because there was very little change in rate of change values overnight. The rate of change refers to the incremental change in DO or DIC concentration over a specified amount of time. DO was measured at $10 \mathrm{~min}$ intervals using a rapid pulse oxygen system (YSI $6030_{i}$ YSI Inc., Yellow Springs, OH, USA; accuracy $\pm 6.25 \mu \mathrm{M}$ ) in conjunction with a multiparameter datalogging system (YSI6000; YSI Inc.) which was secured at about mid-depth $(\sim 0.5 \mathrm{~m})$ in the water column at our site. We calibrated the DO probe in a tank of deionized 
water using Winkler titrations. Following each calibration and prior to each field deployment the data-logger was set to make measurements at $10 \mathrm{~min}$ intervals, placed in a tank of seawater, and checked against Winkler titrations for 1 to $2 \mathrm{~d}$. While the YSI6000 was deployed at our site we collected DO samples close to the instrument using a Van Dorn bottle. These water samples were analyzed for DO using Winkler titrations. Values of DO from the YSI6000 were corrected for the average difference from the field samples (correction ranged 1.3 to $15.9 \mu \mathrm{M})$. Rates of GPP and $R$ were converted into units of carbon using photosynthetic quotients (PQ) of 1.2 and respiratory quotients (RQ) of 1.0 (Oviatt et al. 1986).

DIC samples were collected in $45 \mathrm{ml}$ glass bulbs at 60 or $70 \mathrm{~min}$ intervals from about $0.6 \mathrm{~m}$ depth using a custom built autosampler. The autosampler collected samples under vacuum into glass bulbs kept in the dark. Water samples were preserved upon collection which occurred at $12 \mathrm{~h}$ intervals. Once collected by the autosampler, samples were kept in the dark and isolated from the benthos where most of the GPP and $\mathrm{R}$ was occurring. Therefore, changes in DIC over the $12 \mathrm{~h}$ period prior to preservation were minimal as determined by occasional checks against samples preserved at the time of collection. Subsamples for DIC analysis were transferred from glass bulbs, in duplicate, into $3.7 \mathrm{ml}$ borosilicate vials, fixed with $10 \mu \mathrm{l}$ of $50 \mathrm{mM}$ $\mathrm{HgCl}_{2}$, and tightly capped without headspace. DIC was determined using a Shimadzu TOC 5000 analyzer with standards of sodium bicarbonate and sodium carbonate.

Diel measurements of DO and DIC were used to generate rate of change curves. Rates of change of DO were calculated from the difference between each consecutive DO measurement and plotted against the time each measurement was made to generate a rate of change curve. Individual rate of change values for DO and DIC were corrected for air-water exchange of $\mathrm{O}_{2}$ or $\mathrm{CO}_{2}$ prior to generating the rate of change curve which was used to calculate GPP and R. Gas exchange was estimated using the thin layer boundary (TLB) model, a simple 2-layer model where the main resistance to gas transfer are the gas and liquid film layers (Liss 1973, Liss \& Slater 1974). This model relies on an exchange constant $(k)$ which is a measure of the flux of gas per unit of concentration gradient which is greatly dependent upon the amount of turbulence in gas and liquid phases. The majority of resistance in flux of $\mathrm{O}_{2}$ across the air-water interface is thought to be due to the liquid phase (Liss 1973). We used an empirically derived relationship between wind speed and the gas exchange constant $(k)$ determined from measurements of the losses of added $\mathrm{SF}_{6}$ (sulfur hexafluoride) from lakes of various depths and salinity (Wanninkhof et al.
1991, Wanninkhof 1992). Wind speed data used in gas exchange estimates for Laguna Madre were collected at the South Padre Island Coast Guard Station, about $5 \mathrm{~km}$ from our site, by the Texas A\&M University-Corpus Christi Conrad Blucher Institute. Rates were measured using an anemometer fixed at a $3 \mathrm{~m}$ height, and values were logged at 6 min or $1 \mathrm{~h}$ intervals. For concentrations of $\mathrm{O}_{2}$ and $\mathrm{CO}_{2}$ in air overlying our site we assumed global atmospheric values of $20.95 \%$ and 356 ppm, respectively (Schidlowski 1986, Keeling \& Whorf 1994)

Dissolved $\mathrm{CO}_{2}$ in the water was determined indirectly using DIC, $\mathrm{pH}$, temperature, and salinity data in conjunction with the relationship between DIC species (Stumm \& Morgan 1970), Henry's Law (Weiss 1974), and dissociation constants for carbonic acid in seawater (Roy et al. 1993). The probes for measuring $\mathrm{pH}$, temperature, salinity, and depth were all calibrated prior to each deployment and recorded with the DO data by the YSI-6000 sonde. Salinity was determined from the measurement of specific conductivity which was calibrated using $\mathrm{KCl}$ standards. A temperaturecompensated combination glass electrode was used to measure $\mathrm{pH}$. The electrode was calibrated using $2 \mathrm{pH}$ buffers ( $\mathrm{pH}=7$ and 10, traceable to N.I.S.T., Fisher Scientific). Depth was measured by an installed strain gauge sensor and was checked at least once during each deployment and corrected for height of the gauge from the bottom before use in any calculation.

Discrete measurements of system GPP and R. Separate incubations were conducted to estimate daily GPP and $\mathrm{R}$ of the water column and the benthos. Water was collected around dawn and incubated in 3 or more replicate light and dark bottles for about $12 \mathrm{~h}$ during the day to estimate daytime net primary production (NPP) and R in the water column. Another water sample was collected around sunset and incubated overnight in 3 or more replicate dark bottles to estimate nighttime respiration. These bottle incubations were made during 1 day of every trip to our study site. Water samples were dispensed into clean (acid washed) $300 \mathrm{ml}$ biological oxygen demand (BOD) or $90 \mathrm{ml}$ quartz bottles. Dark bottles were wrapped in aluminum foil and all bottles were incubated in situ on racks set at mid-depth $(\sim 0.5 \mathrm{~m})$ in the water column. Changes in DO were determined by Winkler titration using an automated titrator with potentiometric endpoint detection (Biddanda et al. 1994). A single $50 \mathrm{ml}$ aliquot was taken from each bottle using a volumetric pipette and titrated using $\mathrm{NaS}_{2} \mathrm{O}_{3}$ which was standardized using a standard solution of $0.025 \mathrm{~N} \mathrm{KH}\left(\mathrm{IO}_{3}\right)_{2}$ (Fisher Scientific). Blanks were determined according to Karl et al. (1990). Rates of net $\mathrm{O}_{2}$ production or consumption were determined from the slope of the leastsquare linear regression analysis of the DO concentra- 
tion versus time. Consumption of DO in the dark daytime incubations was added to the DO change in light samples to obtain estimates of GPP in the water column.

Benthic GPP and $R$ were measured following changes in DIC within light and dark in situ chambers. Chambers were constructed from 20 l Nalgene polycarbonate carboys by removing the bottoms and adding a sampling port at the shoulder. Caps of the chambers were fitted with a simple stirring mechanism to mimic in situ water movement. A Savonius rotor (from a current meter) was attached to a rod on the outside of the cap. It was used to generate stirring inside the chamber by turning a propeller attached to the opposite end of the rod that extended about $25 \mathrm{~cm}$ into the chamber. The rod was held in a ballbearing fitting in the cap which allowed it to freely rotate with the rotor which was turned by the surrounding water current. Stirring was verified by observation several times during each incubation. Covers for the chambers were constructed of dark gray plastic and used for the dark incubations.

Four chambers were placed carefully about $8 \mathrm{~cm}$ into the sediment at 3 seagrass dominated sites (primarily Thalassia testudinum) and 1 unvegetated area (void of all macrophytes) adjacent to the other chambers. An average of the 4 chambers was used to estimate benthic metabolism in Laguna Madre. The distribution of chambers was based on estimates of the areal coverage of seagrasses (75\%) and unvegetated $(25 \%)$ sediments in the Laguna Madre (Quammen \& Onuf 1993). Chambers were deployed without caps the night prior to the benthic measurements to minimize the effects of disturbance on metabolism measurements. At dawn, water in the chambers was exchanged with overlying water using a bilge pump ( 34 $\left.1 \mathrm{~min}^{-1}\right)$ held in the chamber for at least 2 min. Dark incubations were conducted early in the morning and late in the afternoon to avoid dramatic shifts in light levels. Benthic incubations lasted for 1.5 to 4 h depending upon level of activity (i.e. winter incubations were longest and summer incubations were shortest). Samples for DIC were collected through the sampling port using a $60 \mathrm{ml}$ syringe after spinning the propeller in each chamber for $2 \mathrm{~min}$ to provide thorough mixing

Daily benthic GPP and R rates were corrected for the volume of each individual chamber. After completion of all benthic incubations, volumes for all 4 chambers were determined by injecting each with $15 \mathrm{ml}$ of $30 \mathrm{mM} \mathrm{NaNO}$. Each chamber was than stirred for 2 min before a sample was collected and later frozen. The concentration of $\mathrm{NO}_{3}{ }^{-}$in these samples was used to estimate the volume of each chamber during every trip. The daily rates of NPP for all incubations were based on the number of daylight hours and $24 \mathrm{~h}$ for the dark incubations $(R)$. The number of hours of light for each day was based on the number of hours of saturating photosynthetically active radiation (PAR) light for seagrasses $\left(-300 \mu \mathrm{E} \mathrm{m}^{-2} \mathrm{~s}^{-1}\right.$ ) (Herzka \& Dunton 1996). GPP was estimated for each individual chamber by adding the average DIC production rates measured in the dark obtained for that chamber to the corresponding average DIC consumption measured in the light. Benthic GPP and R rates were all corrected for water column GPP and R. Values for benthic GPP and R are reported as an average of the 4 chambers $\pm 1 \sigma$.

PAR measurements were collected at our site using a IL1700 radiometer (International Light Inc.) with a flat broad band, submersible detector (PAR SUL033) with a spectral response of 400 to $700 \mathrm{~nm}$. Measurements were made at $10 \mathrm{~cm}$ intervals from the surface to the bottom of the water column a few times throughout at least 1 day on each trip. PAR was also monitored continuously using a LI-193SA spherical quantum sensor in conjunction with an LI-1000 datalogger (LI-COR Inc., Lincoln, NE, USA) at a site adjacent to ours ( $\mathrm{K}$. Dunton, J. Kaldy \& J. Kowalski unpubl. data). The photon flux density ( $\mu \mathrm{mol} \mathrm{m} \mathrm{m}^{-2} \mathrm{~s}^{-1}$ ) was measured at $1 \mathrm{~min}$ intervals underwater at the seagrass canopy level $(\sim 25 \mathrm{~cm}$ from bottom) and was integrated hourly and logged. This data was summed over a $24 \mathrm{~h}$ period to calculate a daily photon flux $\left(E \mathrm{~m}^{-2} \mathrm{~d}^{-1}\right)$. Fluxes obtained with the IL1700 at our site were, on average, $16 \%$ lower than those measured with the LICOR spherical sensor at the adjacent site, and trends in data between the 2 instruments were similar. We used the continuous data in order to relate daily rates of metabolism to total daily flux of PAR.

Annual estimates of GPP and R. Annual weighted averages were calculated for water column GPP and $\mathrm{R}$ by applying the daily rates measured to the month when the measurements were made, and to either the previous or following month. These daily rates were multiplied by the number of days in the given month and the monthly rates were totaled to calculate annual water column GPP and R. The annual estimate of benthic GPP was calculated from the linear regression of benthic GPP versus the corresponding daily PAR flux $\left(\mathrm{n}=7, \mathrm{r}^{2}=0.89, \mathrm{p}=0.001\right.$ ), applying this relationship to continuous PAR collected from June 1996 through June 1997. The annual estimate of benthic $R$ was estimated from benthic $R$ versus average daily water temperature $(T)\left(n=7, r^{2}=0.73, p=0.014\right)$, and applying it to continuous T data collected from June 1996 through June 1997. Ecosystem metabolism estimates were calculated from the linear regression of ecosystem GPP estimates obtained with the open-water method using DO versus the corresponding daily PAR flux $(\mathrm{n}=17$, $\left.r^{2}=0.61, p<0.001\right)$, and ecosystem $R$ estimates obtained using the open-water method with $D O$ versus 
average daily $T\left(n=17, r^{2}=0.68, p<0.001\right)$. These relationships were applied to the continuous PAR and T data collected from June 1996 through June 1997. The error in these estimates is presented as the standard deviation. This was calculated from cumulative error of each daily estimate predicted from the regression analysis throughout the year, and therefore reflects the error of the regression analysis itself.

Statistical analysis. Results of the GPP and R estimated from the 3 different methods were compared using a nonparametric test for matched pairs (Wilcoxon 1945, 1947). This analysis was calculated using Systat version 5.2 for Windows (Systat, Inc., 1992). Significance for these tests was set at $p<0.05$.

\section{RESULTS AND DISCUSSION}

\section{Comparison of open-water approaches to measure ecosystem GPP and $R$}

Ecosystem GPP and R estimated for Laguna Madre employing the open-water method with DO ranged from 56 to 366 and 103 to $381 \mathrm{mmol} \mathrm{C} \mathrm{m}{ }^{-2} \mathrm{~d}^{-1}$, respectively (Table 1). Daily rates for ecosystem GPP and $\mathrm{R}$ using DIC ranged from 365 to 863 and 335 to $931 \mathrm{mmol}$ $\mathrm{C} \mathrm{m}^{-2} \mathrm{~d}^{-1}$, respectively, and were significantly greater

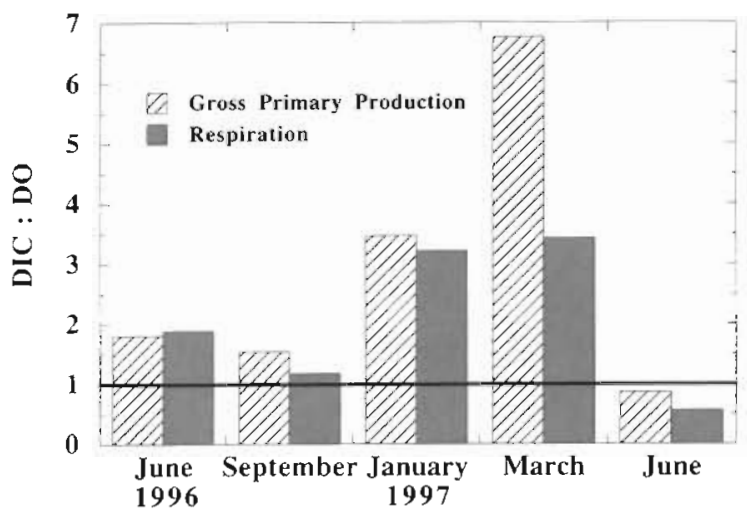

Fig. 1. Ratios of ecosystem gross primary production (GPP) measured using the open-water method with dissolved inorganic carbon (DIC) to GPP measured using the open-water method with dissolved oxygen (DO), and ratios of ecosystem respiration ( $R$ ) measured using the open-water method with DIC to $R$ measured using the open-water method with DO from June 1996 to June 1997. DIC:DO refers to the ratios of rates (either GPP or R) measured using DIC to those measured using DO

than those estimated based on DO measurements (Wilcoxon; $\mathrm{p}=0.01, \mathrm{n}=5$ for GPP; $\mathrm{p}=0.04, \mathrm{n}=5$ for $\mathrm{R}$ ). The ratios of GPP and $R$ rates estimated using DIC to those estimated using DO ranged from 0.9 to 6.8 for GPP and 0.6 to 3.4 for R (Fig. 1). We considered 4 major

Table 1. Average gross primary production (GPP), respiration (R), and corresponding GPP to $R$ ratios (P:R) based on open-water and discrete measurements. Means and standard deviation or percent mean deviation for the open-water values are based on replicate days during a given trip. Means and standard deviations for discrete values are based on the summation of the mean of water column ( $n \geq 3$ ) plus benthic measurements $(n=4)$ for a single day during each trip. nd: not determined

\begin{tabular}{|c|c|c|c|c|c|c|c|}
\hline Date & $\mathrm{n}$ & $\begin{array}{c}\mathrm{GPP} \\
\left(\mathrm{mmol} \mathrm{C} \mathrm{m}^{-2} \mathrm{~d}^{-1}\right)\end{array}$ & $1 \sigma$ & 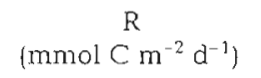 & $1 \sigma$ & $P: R$ & $1 \sigma^{*}$ \\
\hline \multicolumn{8}{|c|}{ Open-water method using DO } \\
\hline February & 1 & 102.65 & nd & 138.07 & nd & 0.74 & nd \\
\hline April & 3 & 220.54 & 4.6 & 217.52 & 20.2 & 1.01 & 0.09 \\
\hline June & 3 & 365.74 & 45.5 & 381.04 & 19.3 & 0.96 & 0.13 \\
\hline July & - & nd & nd & nd & nd & nd & nd \\
\hline September & 3 & 237.39 & 3.7 & 284.48 & 19.4 & 0.83 & 0.07 \\
\hline November & - & nd & nd & nd & nd & nd & nd \\
\hline January & 2 & 55.70 & 9.1 & 102.96 & 23.0 & 0.54 & nd \\
\hline March & 2 & 127.69 & 37.6 & 271.11 & 19.9 & 0.47 & nd \\
\hline June & 2 & 263.63 & 17.3 & 315.36 & 24.1 & 0.84 & nd \\
\hline \multicolumn{8}{|c|}{ Summation of discrete measurements } \\
\hline February & - & nd & nd & nd & nd & nd & nd \\
\hline April & - & nd & nd & $n d$ & nd & nd & nd \\
\hline June & 4 & 193.78 & 100.6 & 180.55 & 107.8 & 1.07 & 1.01 \\
\hline July & 4 & 233.04 & 112.5 & 207.02 & 119.0 & 1.13 & 0.93 \\
\hline September & 4 & 214.50 & 68.1 & 217.89 & 80.4 & 0.98 & 0.65 \\
\hline November & 4 & 124.00 & 60.7 & 129.29 & 53.5 & 0.96 & 0.64 \\
\hline January & 4 & 80.46 & 20.4 & 54.11 & 26.2 & 1.49 & 0.55 \\
\hline March & 4 & 102.20 & 43.0 & 79.10 & 38.9 & 1.29 & 0.66 \\
\hline June & 4 & 146.70 & 74.3 & 149.9 & 95.3 & 0.98 & 0.81 \\
\hline
\end{tabular}


reasons for the observed discrepancy: (1) the influence of air-water exchange of $\mathrm{O}_{2}$, (2) problems of $\mathrm{O}_{2}$ supersaturation in the water column, (3) the use of photosynthetic and respiratory quotients (PQ and $R Q$ ) to convert the DO data into carbon units, (4) the effect of water movement.

Gas exchange across the air-water interface has always been a problem in the calculation of GPP and $\mathrm{R}$ using the open-water method. The relationship between wind speed and the gas exchange coefficient used in this study was developed from data sets of wind speeds that did not exceed $8 \mathrm{~m} \mathrm{~s}^{-1}$ over lakes varying in area from 0.13 to $200 \mathrm{~km}^{2}$ (Wanninkhof et al. 1991, Wanninkhof 1992). However, in Laguna Madre wind speeds exceeded this limit during frontal passages, and due to the shape of Laguna Madre (i.e. elongated in N-S direction) the fetch at the water surface is greatly increased at our field site when the wind is from the north (Fig. 1). In November 1996 high wind speeds from the north, due to a passing front, caused overestimates of daily $\mathrm{R}$ rates. Another potential source of error in the estimation of gas exchange was the use of wind data collected $5 \mathrm{~km}$ from our site. Although our estimations of gas exchange may be a source of error, this exchange represented at most $30 \%$, and on average only about $10 \%$, of the metabolic rates measured in this study. It was not significant enough to explain the difference between GPP and $R$ measured using DO and DIC data.

Supersaturation is more likely to influence values of DO because $\mathrm{CO}_{2}$ represents only a small fraction of the DIC complex in seawater. Furthermore, supersaturation is more of a problem for the estimation of GPP than $\mathrm{R}$ since it would be expected to occur during daylight when water temperatures and primary production are highest. However, the difference in GPP estimated using DO and DIC was similar to the difference in the 2 estimates of $\mathrm{R}$, except during March 1997 (Fig 1). Saturation of DO ranged from 50 to $130 \%$ relative to atmospheric equilibrium concentrations. Supersaturation of $\mathrm{O}_{2}$ was more common in the warmest months, however we did not observe a greater ratio of measurements by DIC to DO for either GPP or R during this time of year in comparison to the colder months. In fact, we observed the opposite trend.

We used a photosynthetic quotient (PQ) range of 1.03 to 1.30 and a respiratory quotient (RQ) range of 0.8 to 1.14 pooled from studies of benthic dominated systems to test the effect of these quotients on the difference in GPP and R estimated using DIC versus DO data (Park et al. 1958, Odum 1963, Lindeboom \& DeBree 1982, Oviatt et al. 1986, Erftemeijer et al. 1993, Clavier et al. 1994). The resulting range of DIC to DO ratios for the measurements of GPP and $\mathrm{R}(0.74$ to 7.32 and 1.03 to 4.29 , respectively) varied only slightly from the original ratios of DIC to DO estimates ( 0.86 to 6.76 for GPP and 0.56 to 3.43 for $R$ ). The $P Q$ and $R Q$ were not a major factor influencing the difference between the 2 open-water measurements.

The reservoir sizes of DIC and DO relative to biological consumption or production in Laguna Madre differ greatly. The turnover time for DIC ( 6 to $49 \mathrm{~d}$ ) was much longer than for DO (0.6 to $6 \mathrm{~d}$ ). The effect of the turnover time of DIC was illustrated by the diel DIC curve for January 19 to 20, 1997. Water movement appeared to have influenced the concentration of DIC at night, and had no apparent effect on the diel curve of DO (Fig. 2). The problem of water advection was observed in 6 of the 13 diel DIC curves and not in any DO curve. The largest differences between the 2 estimates occurred in the least productive times of the year when advection had the greatest influence. However, diel DIC curves collected when tidal exchange was weak and the biological signal was strong were

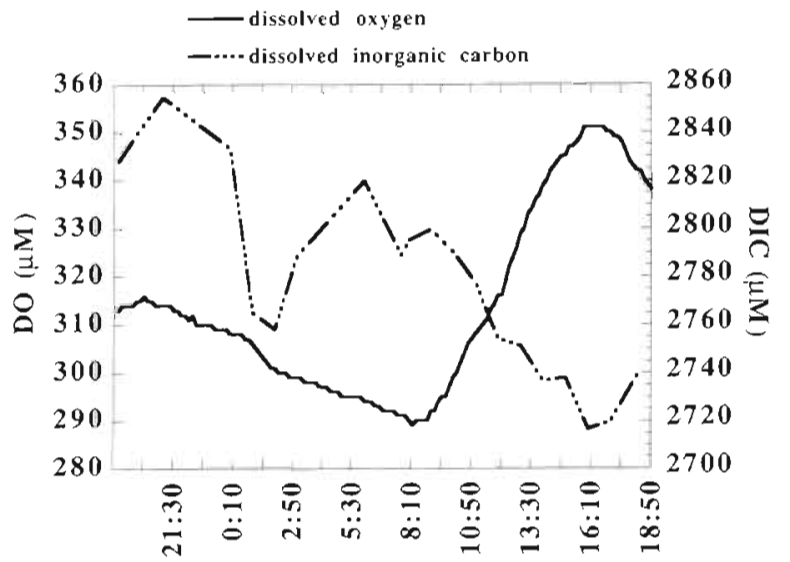

Fig. 2. Water column diel measurements of dissolved oxygen (DO) and dissolved inorganic carbon (DIC) for lower Laguna Madre during January 19 to 20, 1997

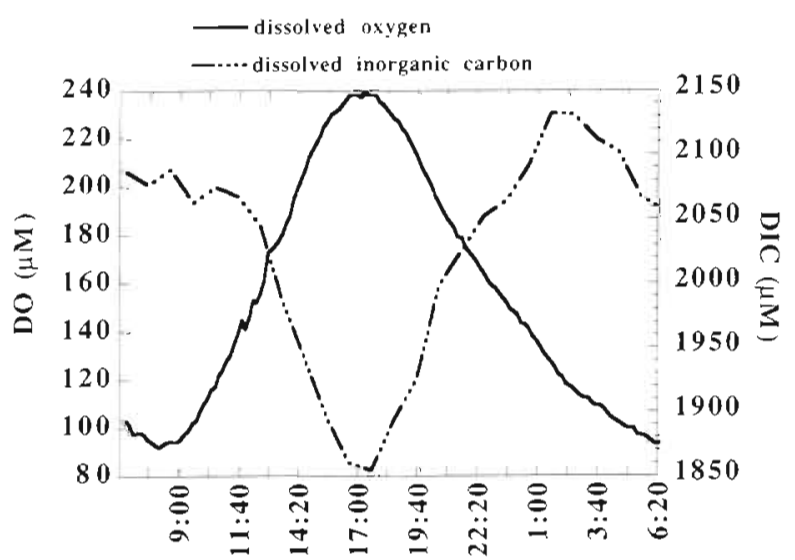

Fig. 3. Water column diel measurements of dissolved oxygen (DO) and dissolved inorganic carbon (DIC) for lower Laguna Madre during September 11 to 12, 1996 
inversely related to the corresponding diel DO curves (Fig. 3).

Seagrasses are the major primary producers in Laguna Madre and their rates of production have been reported to be controlled primarily by water temperature and PAR irradiance (Herzka \& Dunton 1996, Lee \& Dunton 1996). The regression analyses of GPP estimated using DO and DIC versus temperature and PAR demonstrated that only the GPP rates estimated using DO were related to these parameters (Fig. 4a, b). Het-
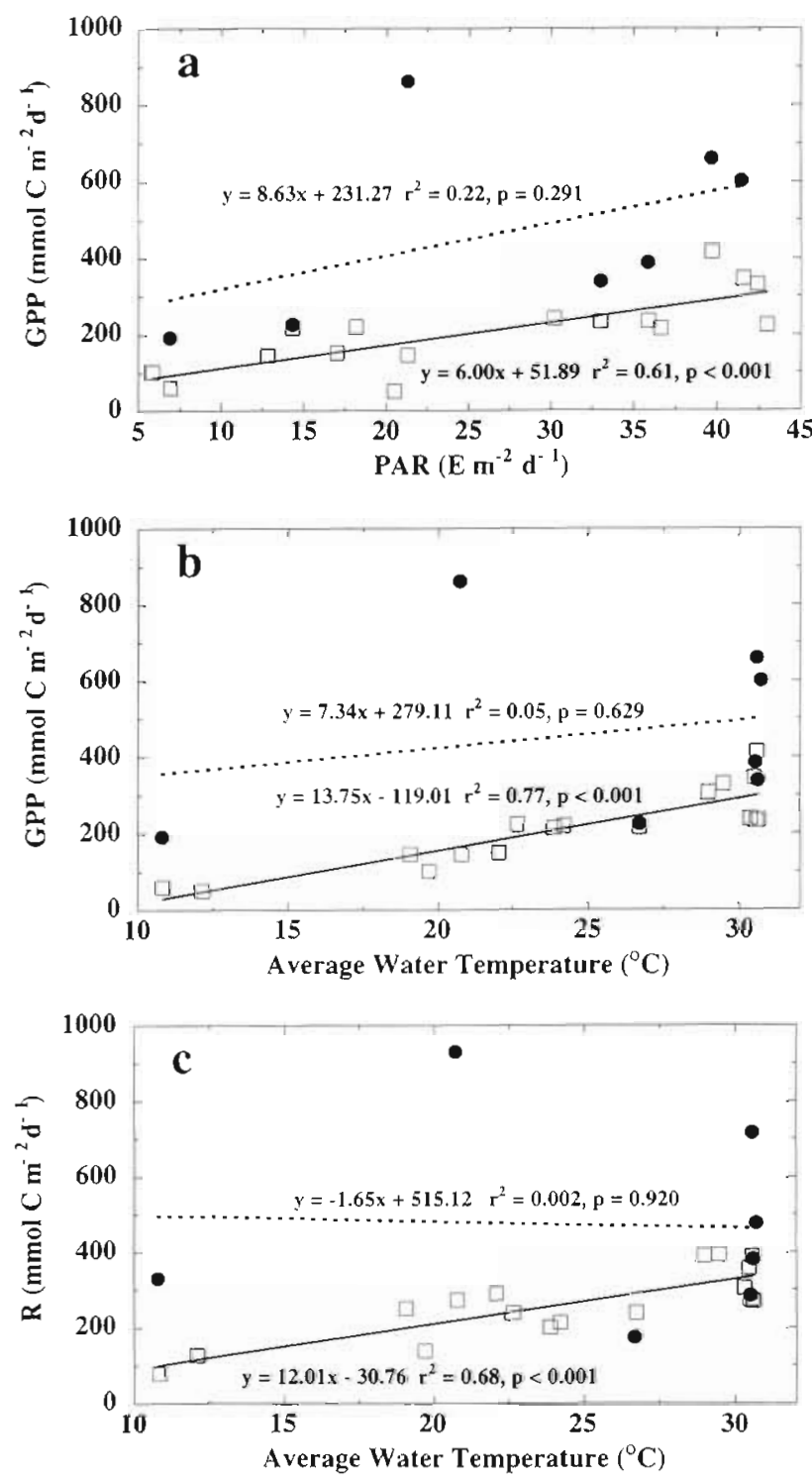

Fig. 4. Ecosystem gross primary production (GPP) determined using open-water method with dissolved oxygen (DO) $(n=17)$ $(-\square-)$ and dissolved inorganic carbon (DIC) (n= 7$)(\ldots-\cdots)$ versus (a) in situ, underwater, daily photosynthetically active radiation (PAR) flux, and (b) daily average water temperature. (c) Ecosystem respiration (R) determined using open-water method with DO $(n=17)(-\square-)$ and DIC $(n=7)(\cdots \bullet \cdots)$ versus daily average water temperature erotrophic bacterioplankton growth was also reported to be correlated with temperature in Laguna Madre (Chin-Leo \& Benner 1991). Temperature was correlated to, and accounted for much of the variability in, estimates of $\mathrm{R}$ using $\mathrm{DO}$ but not for $\mathrm{R}$ estimated using DIC (Fig. 4c). The fact that GPP and R estimated using DIC data were not correlated to PAR or temperature indicated that the use of DIC to estimate ecosystem GPP and R may not have been appropriate in this system, and the estimates using DO were probably more robust.

\section{Open-water approach versus discrete measurements of ecosystem GPP and R}

The seasonal trends in GPP and R for both the discrete and open-water DO methods were similar. Both approaches indicated a peak in GGP and $R$ in early to mid-summer, a decrease in mid-winter, and a subsequent increase in early summer (Fig. 5a, b; Table 1). Regression analysis of GPP estimated by the discrete approach versus total daily PAR and temperature indi-
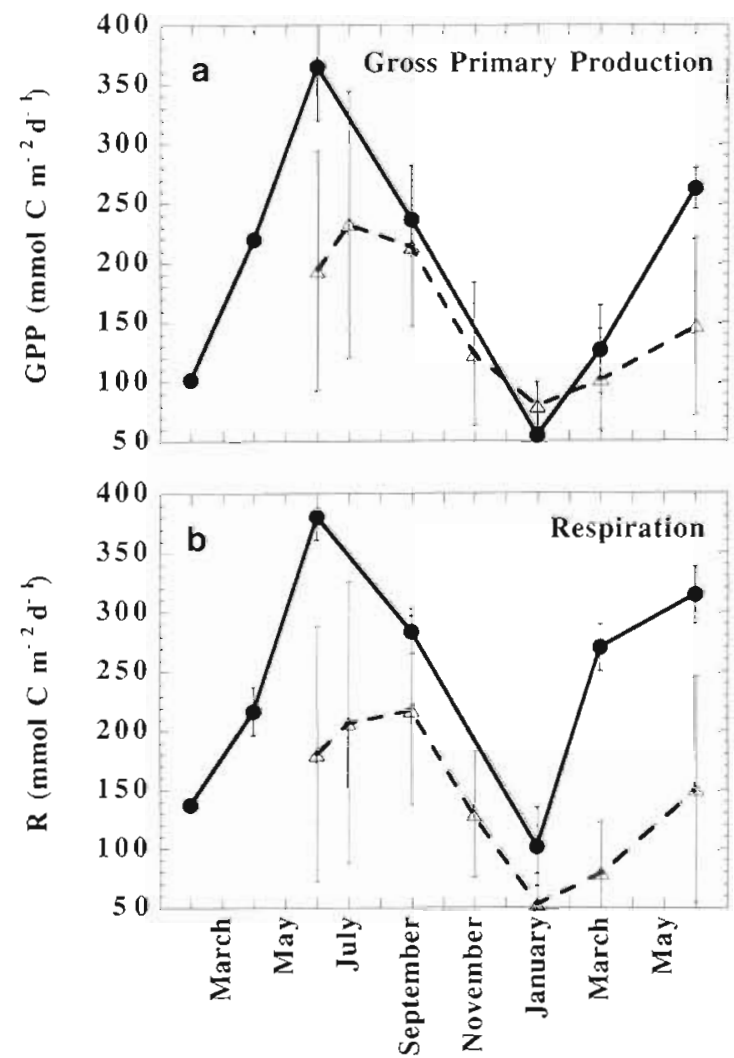

Fig. 5. Ecosystem level (a) gross primary production and (b) respiration determined by open-water method using dissolved oxygen (- - ) , and discrete methods $(--\Delta--)$. Error bars represent $1 \sigma$ 

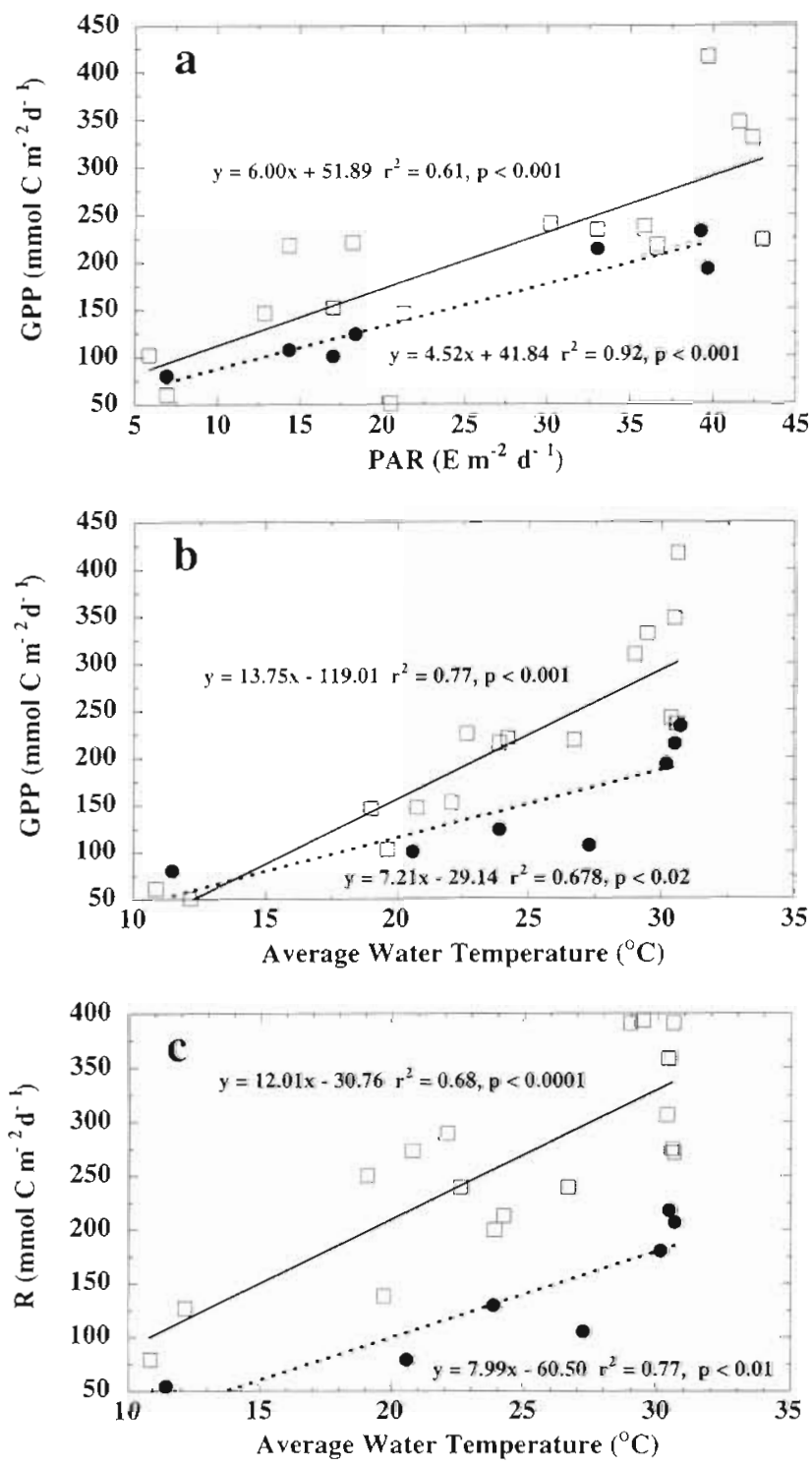

Fig. 6. Ecosystem gross primary production (GPP) determined using discrete $(n=7)(\cdots \cdot \cdots)$ and open-water methods $(n=17)$ $(-\square-)$ using dissolved oxygen (DOi versus (a) in situ, underwater, daily PAR flux, and (b) daily average water temperature. (c) Ecosystem level respiration ( $R$ ) determined using discrete $(n=7)(\ldots-\cdots)$ and open-water methods $(n=17)$ ( $\square-$ ) using dissolved oxygen versus daily average water temperature

cated that both of these variables are correlated to, and can explain most of the variability in, the discrete measurements of GPP (Fig. 6a, b). Temperature was correlated to, and explained much of the variability in, the estimate of $R$ by the discrete method (Fig. 6c). The open-water DO estimates of $R$ were significantly higher than the discrete estimates (Wilcoxon, $\mathrm{p}=0.02$, $n=5$ ). However, the GPP rates estimated using the discrete methods were not significantly different from the open-water estimates (Wilcoxon, $\mathrm{p}=0.40, \mathrm{n}=5$ ).

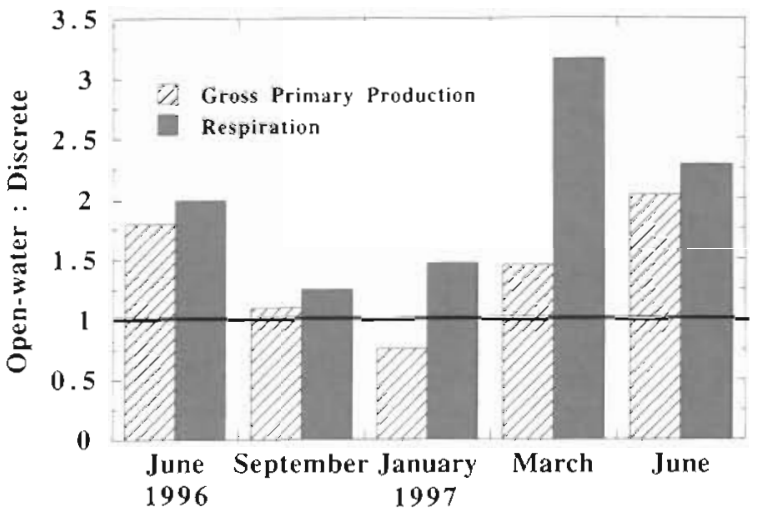

Fig. 7 Ratios of ecosystem gross primary production (GPP) measured using the open-water method with dissolved oxygen (DO) to GPP measured using discrete methods, and ratios of ecosystem respiration $(R)$ measured using the open-water method with $\mathrm{DO}$ to $\mathrm{R}$ measured using discrete methods from June 1996 to June 1997

The ratio of the open-water DO estimates of GPP and $\mathrm{R}$ to those estimated by the discrete measurements ranged from 0.8 to 2.0 for GPP and 1.3 to 3.2 for $R$ (Fig. 7). Other studies in estuarine systems report similar ratios (1.1 to 4.0 ) for these 2 approaches and have primarily attributed this to the effect of physical processes (Odum \& Hoskin 1958, Verduin 1960, Kemp \& Boynton 1980). The differences between the openwater and discrete measurements in Laguna Madre do not appear to be due to effects of the enclosures used in the discrete measurements. In the Laguna Madre lower metabolic rates estimated by the discrete versus the open-water method were not apparent at times of

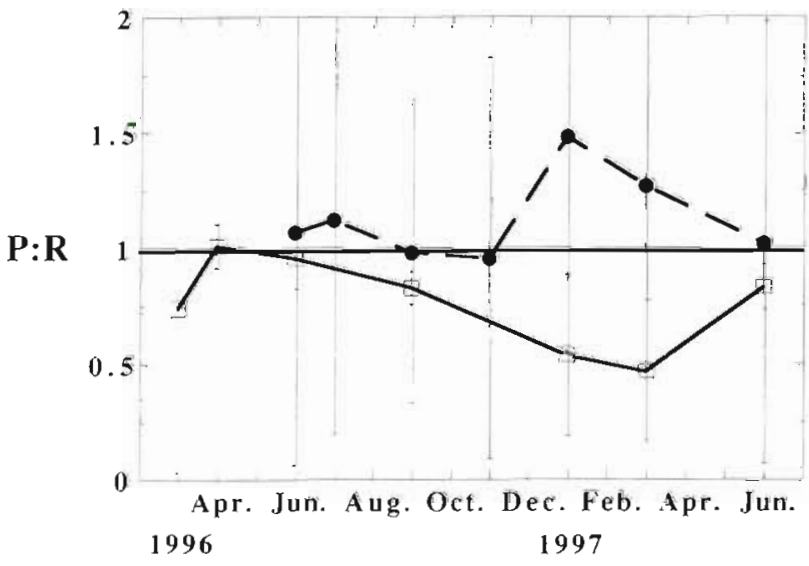

Fig. 8. Ecosystem gross primary production to respiration ratios (P:R) for measurements made using the open-water method (- $\square$-) with dissolved oxygen and summation of discrete methods (- - - ). Error bars represent $1 \sigma$ except for the open water estimates made during January, March, and June 1997 where $\mathrm{n}=2$ and the error bars represent the percent mean deviation and February 1996 where $\mathrm{n}=1$. and no estimate of error is provided 
higher activity when enclosures would be expected to have the greatest effect on metabolic rates. During September 1996, when metabolic rates were just below the annual peak, the methods yielded the most similar rates (Fig. 7). The use of short incubations and ambient stirring within the chambers probably reduced the effect of the enclosures.

The P:R ratios calculated from the open-water and discrete methods were different and varied seasonally. The $P: R$ ratios calculated from the open-water method indicated that the system was net heterotrophic $(\mathrm{P}: \mathrm{R}<$ 1) during winter and early spring, whereas the discrete method indicated that the system was net autotrophic (P:R $>1$ ) during these periods (Fig. 8). The difference in these ratios is primarily due to differences in the estimation of $\mathrm{R}$. In fact, a seasonal pattern in this difference was apparent in the ratio of $R$ estimated by the openwater method to $R$ estimated by the discrete approach (Fig. 7). The largest difference in $\mathrm{R}$ was measured in March and the smallest in September. The live aboveground biomass and density of Thalassia testudinum in Laguna Madre was reported to have peaked in September $\left(\sim 160 \mathrm{gdw} \mathrm{m}^{-2}\right)$ and decreased rapidly between December and February, with the lowest biomass $\left(\sim 75 \mathrm{gdw} \mathrm{m}^{-2}\right)$ in March (Kaldy 1997). Large rafts of seagrass blades are often seen in late winter and early spring in Laguna Madre (Onuf 1996). This additional R in the system may be due to the microbial utilization of suspended seagrass detritus which is most abundant in late winter and early spring. However, this could only explain a minor fraction of the difference in the $\mathrm{R}$ measurements by the 2 independent methods.

The observed differences between the measurements of $\mathrm{R}$ by these 2 methods is more likely due to errors inherent to the open-water method. Influences of water movement on changes in DO concentrations may have gone undetected as opposed to the changes in concentrations of DIC where this influence was very obvious (Fig. 2). Air-water exchange of $\mathrm{O}_{2}$ represented 4 to $30 \%$ of the rates of GPP and R estimated using the open-water method with DO. As mentioned, high wind speeds artificially increased $R$ estimates in November, therefore gas exchange estimates could be responsible for some of the high estimates of $\mathrm{R}$ obtained using the open-water approach. The difference in $\mathrm{R}$ between the 2 approaches on an annual basis was about $49 \%$ of the open-water estimate, therefore the estimate of gas exchange could have been a major factor contributing to the difference between these 2 estimates as it represented up to $30 \%$ of the metabolic rates measured.

Table 2. Estimates of ecosystem gross primary production (GPP) and respiration (R) made in seagrass dominated systems using either the open-water method or summation of discrete measurements using dissolved oxygen

\begin{tabular}{|c|c|c|c|c|c|c|}
\hline Location & $\begin{array}{l}\text { Major seagrass } \\
\text { species }\end{array}$ & $\begin{array}{l}\text { Time of } \\
\text { year }\end{array}$ & $\begin{array}{c}\text { GPP } \\
\left(\mathrm{mmolC} \mathrm{m}^{-2} \mathrm{~d}^{-1}\right)\end{array}$ & $\underset{\left(\mathrm{mmol} \mathrm{C} \mathrm{m} \mathrm{m}^{-2} \mathrm{~d}^{-1}\right)}{\mathrm{R}}$ & Method & Source \\
\hline Coastal Pond, RI, USA & Z. marina & August & $141^{\mathrm{a}}$ & $191^{\text {a }}$ & Open-water & $\begin{array}{l}\text { Nixon \& Oviatt } \\
\text { (1972) }\end{array}$ \\
\hline $\begin{array}{l}\text { Brackish Lake, } \\
\text { The Netherlands }\end{array}$ & Z. marina & $\begin{array}{l}\text { March- } \\
\text { October }\end{array}$ & $16-94$ & $4-31$ & $\begin{array}{c}\text { Discrete } \\
\text { (benthos only) }\end{array}$ & $\begin{array}{l}\text { Lindeboom \& } \\
\text { DeBree (1982) }\end{array}$ \\
\hline $\begin{array}{l}\text { Chesapeake Bay, } \\
\text { VA, USA }\end{array}$ & Z. marina & $\begin{array}{l}\text { Annual } \\
\text { average }\end{array}$ & 132 & 82 & Discrete & $\begin{array}{l}\text { Murray \& } \\
\text { Wetzel (1987) }\end{array}$ \\
\hline $\begin{array}{l}\text { Flores Sea, } \\
\text { E. Indonesia }\end{array}$ & T. hemprichii & $\begin{array}{l}\text { October } \\
\text { (spring) }\end{array}$ & $103-392$ & $72-371$ & Discrete & $\begin{array}{l}\text { Lindeboom \& } \\
\text { Sandee (1989) }\end{array}$ \\
\hline $\begin{array}{l}\text { Coastal flats and reef, } \\
\text { So. Sulawesi, Indonesia }\end{array}$ & T. hemprichii & $\begin{array}{l}\text { April-- } \\
\text { August }\end{array}$ & $75-367$ & $117-425$ & $\begin{array}{c}\text { Discrete } \\
\text { (benthos only) }\end{array}$ & $\begin{array}{l}\text { Erftemeijer } \\
\text { et al. (1993) }\end{array}$ \\
\hline Redfish Bay, TX, USA & T. testudium & $\begin{array}{l}\text { Annual } \\
\text { average }\end{array}$ & $428^{d}$ & $531^{\star}$ & Open-water & $\begin{array}{l}\text { Odum \& Hoskin } \\
\text { (1958) }\end{array}$ \\
\hline $\begin{array}{l}\text { Upper Laguna Madre, } \\
\text { TX, USA }\end{array}$ & H. wrightii & $\begin{array}{l}\text { Annual } \\
\text { average }\end{array}$ & $161^{\mathrm{d}}$ & $175^{\prime \prime}$ & Open-water & $\begin{array}{l}\text { Odum \& Hoskin } \\
\text { (1958) }\end{array}$ \\
\hline $\begin{array}{l}\text { Lower Laguna Madre, } \\
\text { TX, USA }\end{array}$ & $T$. testudium & $\begin{array}{l}\text { July- } \\
\text { August }\end{array}$ & 566 & 446 & Open-water & $\begin{array}{l}\text { Odum \& Wilson } \\
\text { (1962) }\end{array}$ \\
\hline $\begin{array}{l}\text { Lower Laguna Madre, } \\
\text { TX, USA }\end{array}$ & $T$ testudium & $\begin{array}{l}\text { Annual } \\
\text { range }\end{array}$ & $81-233$ & $54-217$ & Discrete & This study \\
\hline $\begin{array}{l}\text { Lower Laguna Madre, } \\
\text { TX, USA }\end{array}$ & $T$ testudium & $\begin{array}{l}\text { Annual } \\
\text { range }\end{array}$ & $56-366$ & $103-381$ & Open-water & This study \\
\hline
\end{tabular}




\section{Ecosystem metabolism of a seagrass meadow}

The GPP of this seagrass meadow in Laguna Madre was close to the low end of the range of values reported for salt marshes, some of the most productive ecosystems whose annual production ranges from about 80 to $360 \mathrm{~mol} \mathrm{C} \mathrm{m}{ }^{2} \mathrm{yr}^{-1}$ (Nixon \& Oviatt 1973, Hopkinson 1988). Rates of ecosystem GPP and $R$ in Laguna Madre were higher than those reported for temperate seagrass communities dominated by Zostera marina, and lower than the average rates for communities dominated by the tropical seagrass Thalassia hemprichii (Table 2). Although net metabolism cannot be quantitatively determined from the individual estimates of GPP and $R$, the results of this study do indicate that the GPP and R of the seagrass community in Laguna Madre appear to be nearly balanced. Summer estimates of ecosystem GPP and R in Laguna Madre reported by Odum \& Wilson (1962) were higher than those determined in this study. This discrepancy may have to do with changes in both the species and biomass of seagrasses since the 1960s. There has been an increase in the coverage of both $T$. testudinum and Syringodium filiforme in Laguna Madre since the 1970s (Onuf 1996).

The benthos was the primary contributor to the total system GPP and R in Laguna Madre (Table 3). Benthic GPP and $\mathrm{R}$ represented $-97 \%$ and $-89 \%$, respectively, of total system GPP and R estimated by the discrete technique. However, in January 1997 the benthos contributed only $57 \%$ and $74 \%$ of total GPP and R, respectively, during a phytoplankton bloom. Based on leaf and root marking techniques, NPP of Thalassia testudinum was estimated to be about $29 \mathrm{~mol} \mathrm{C} \mathrm{m}^{-2} \mathrm{yr}^{1}$ within the $T$. testudinum meadow where our site was located (Kaldy 1997). The NPP of $T$. testudinum represented about $51 \%$ of the total benthic GPP and about $210 \%$ of the total benthic NPP measured in the present study (Table 3 ). This indicated that $T$ testudinum was a major contributor to primary production of the sea-

Table 3. Annual estimates of ecosystem gross primary production (GPP) and respiration $(R)$ were calculated by applying results of the regression analyses of GPP and R, estimated from both the open-water and discrete methods, versus daily photosynthetically active radiation (PAR) and average daily water temperature, respectively, to daily measurements of total PAR flux and average daily water temperature collected from June 1996 to June 1997

\begin{tabular}{|lcccccc|}
\hline Method & $\begin{array}{c}\text { GPP } \\
\left(\mathrm{mol} \mathrm{m}^{-2} \mathrm{yr}^{-1}\right)\end{array}$ & $1 \sigma$ & $\mathrm{R}$ & $1 \sigma$ & $\mathrm{P}: \mathrm{R}$ & $1 \sigma$ \\
\hline $\begin{array}{l}\text { Open-water } \\
\text { method. using DO }\end{array}$ & 61.4 & 36.6 & 90.0 & 22.0 & 0.68 & 0.64 \\
$\begin{array}{l}\text { Summation of } \\
\text { discrete measures }\end{array}$ & 49.5 & 16.9 & 46.2 & 5.4 & 1.07 & 0.36 \\
\hline
\end{tabular}

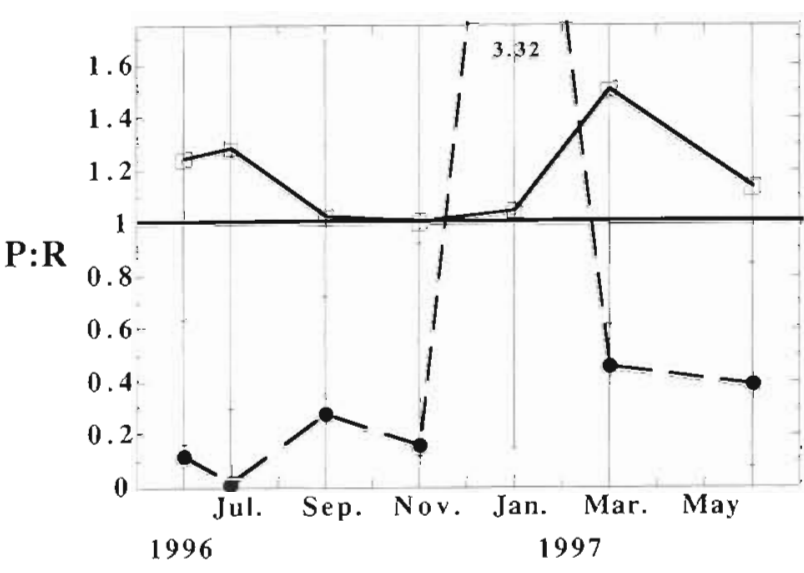

Fig. 9. Water column and benthic gross primary production to respiration (P:R) ratios for June 1996 through June 1997. Error bars represent $1 \sigma$

grass meadow studied and much of its production was consumed in the benthos. This comparison also indicates that epiphytes and benthic algae were also potentially important contributors to the primary productivity of the system.

The water column GPP and $\mathrm{R}$ estimates indicated that it was net heterotrophic most of the year with $P: R$ values that ranged from 0.01 to 0.45 (Fig. 9). An exception to the overall heterotrophic nature of the water column accurred in January 1997 (P:R = 3.32). High water column GPP (35 mmol $\mathrm{C} \mathrm{m}^{-2} \mathrm{~d}^{-1}$ ) measured in January was due to a brown tide bloom that was blown into lower Laguna Madre from upper Laguna Madre by strong north winds. The rates of GPP and $R$ and the $P: R$ ratios of the water column at our site were similar to those reported in other Thalassia testudinum meadows in Texas and Puerto Rico (Odum \& Hoskin 1958, Odum et al. 1959). High water column GPP rates were reported for Posidonia oceanica, Zostera marina, and Ruppia maritima meadows where rates ranged from about 40 to $120 \mathrm{mmol} \mathrm{C} \mathrm{m} \mathrm{C}^{-1}$ and accounted for greater than $30 \%$ of the total system GPP (Murray \& Wetzel 1987, Velimirov \& WalentaSimon 1992). The water column in Laguna Madre is not an important site of primary production as it accounts for less than $4 \%$ of the total system GPP.

The benthos was net autotrophic throughout most of the year with $P: R$ values that ranged from 0.96 to 1.49 (Fig. 9). The highest values of benthic P:R occurred in March (Fig. 9) and corresponded to the period of peak photosynthetic tissue biomass (Kaldy 1997). The discrete measurements of GPP and $\mathrm{R}$ within the benthos and water column indicated that they were tightly cou- 
pled. The net heterotrophic water column was fueled by the net autotrophic benthos, most likely through the release of dissolved organic matter. Very few studies have investigated the metabolism of both the water column and benthos in seagrass dominated systems and in Laguna Madre these basic measurements have lead to an increased understanding of how this seagrass system functions.

\section{CONCLUSIONS}

The 2 independent approaches (open-water and discrete) used to estimate ecosystem GPP and R in lower Laguna Madre indicated that GPP and $R$ rates were high and within the range of rates reported for other tropical and temperate seagrass systems. Although the metabolism measurements presented in this study cannot provide an accurate estimation of net metabolism they do indicate that GPP and $R$ in the system are nearly balanced. The discrete measurements revealed that most of the GPP and $R$ of the system occurred in the benthos, and that the autotrophic benthos was fueling the heterotrophic water column through the release of dissolved organic matter.

Acknowledgements. The authors especially thank Beau Hardigree for extensive and essential field and laboratory assistance, which included the construction of the autosampler in association with Ellery Ingall. We also appreciate the assistance of Don Hockaday at the UT-PanAm Coastal Studies Laboratory, South Padre Island, Texas, who provided needed laboratory space and facilities during field trips to LLM. We thank Cheryl Brown of Texas A\&M - Corpus Christi Conrad Blucher lnstitute for providing windspeed and continuous water temperature data. We also thank Ken Dunton, Jim Kaldy, and Joe Kowalski for providing continuous PAR flux data. Thanks also go to Brenda Black, Edith Kaiser, Karl Kaiser, Dan Lara, and Steve Opsahl as well as 3 anonymous reviewers for helpful comments on an earlier draft of the paper. This research was supported by NSF grant DEB 9420652. This is contribution number 1082 from the University of Texas Marine Science Institute.

\section{LITERATURE CITED}

Behrens EW (1966) Surface salinities for Baffin Bay and Laguna Madre, Texas, April 1964 - March 1966. Publ Inst Mar Sci Univ Texas 11:168-173

Biddanda B, Opsahl S, Benner R (1994) Plankton respiration and carbon flux through bacterioplankton on the Louisiana shelf. Limnol Oceanogr 39:1259-1275

Chin-Leo G, Benner R (1991) Dynamics of bacterioplankton abundance and production in seagrass communities of a hypersaline lagoon. Mar Ecol Prog Ser 73:219-230

Clavier J, Boucher G, Garrigue C (1994) Benthic respiratory and photosynthetic quotients in a tropical lagoon. $C R$ Acad Sci Ser III Sci Vie 317(10):937-942

Critchfield H (1974) General climatology, 3rd edn. Prentice Hall, Englewood Cliffs, NJ
D'Avanzo C, Kremer JN, Wainwright SC (1996) Ecosystem production and respiration in response to eutrophication in shallow temperate estuaries. Mar Ecol Prog Ser 141: 263-274

Dunton $\mathrm{KH}$, Tomasko DA (1994) In situ photosynthesis in the seagrass Halodule wrightii in a hypersaline subtropical lagoon. Mar Ecol Prog Ser 107:281-293

Erftemeijer PLA, Osinga R, Mars AE (1993) Primary production of seagrass beds in South Sulawesi (Indonesia): a comparison of habitats, methods and species. Aquat Bot $46: 67-90$

Fontaine TD, Ewel KC (1981) Metabolism of a Florida lake ecosystem. Limnol Oceanogr 26(4):754-763

Hedgepeth JW (1967) Ecological aspects of the Laguna Madre, a hypersaline estuary. In: Lauff GH (ed) Estuaries. American Association for the Advancement of Science, Washington, DC, p 408-420

Herzka SZ, Dunton KH (1996) Seasonal photosynthetic patterns of the seagrass Thalassia testudinum in the western. Gulf of Mexico. Mar Ecol Prog Ser 152:103-117

Hopkinson CS (1988) Patterns of organic carbon exchange between coastal ecosystems: the mass balance approach in salt marsh ecosystems. In: Jansson BO (ed) Coastal offshore ecosystem interactions. Springer-Verlag, New York, p $122-154$

Howarth RW, Marino R, Garritt R, Sherman D (1992) Ecosystem respiration and organic carbon processing in a large, tidally influenced river: the Hudson River. Biogeochemistry $16: 83-102$

Humm HJ. Hildebrand HH (1962) Marine algae from the gulf coast of Texas and Mexico. Publ Inst Mar Sci Univ Texas $8: 227-268$

Kaldy JE (1997) Production dynamics, reproductive ecology and demography of Thalassia testudinum (turtle grass) from the Lower Laguna Madre, Texas. PhD dissertation, University of Texas at Austin

Karl DM, Winn CD, Hebel DV, Letelier R, Chriswell S, Walsh TW, Bird DF (1990) Hawaii Ocean Time-Series Program Field and Laboratory Protocols, University of Hawaii Press, Honolulu

Keeling CD, Whorf TP (1994) Atmospheric $\mathrm{CO}_{2}$ records from sites in $\mathrm{S} 10$ air sampling network. In: Boden TA, Kaiser DP, Sepanski RJ, Stoss FW (eds) Trend '93: a compendium of data on global change. Carbon Dioxide Information Analysis Center, Oak Ridge Natl Lab, Oak Ridge, TN, p $16-26$

Kelly MG, Hornberger GM, Cosby BJ (1974) Continuous automated measurement of rates of photosynthesis and respiration in an undisturbed river community. Limnol Oceanogr 19(2):305-312

Kemp WM, Boynton WR (1980) Influence of biological and physical processes on dissolved oxygen dynamics in an estuarine system: implications for measurement of community metabolism. Estuar Coast Mar Sci 11:407-431

Larkum AWD, McComb AJ, Shepherd SA (1989) Biology of seagrasses. Elsevier Science Publ Co, New York

Lee $\mathrm{K}$, Dunton KH (1996) Production and carbon reserve dynamics of the seagrass Thalassia testudinum in Corpus Christi Bay, Texas, USA. Mar Ecol Prog Ser 143:201-210

Lindeboom HJ, DeBree BHH (1982) Daily production and consumption in an eelgrass (Zostera manina) community in saline lake Grevelingen: discrepancies between the $\mathrm{O}_{2}$ and ${ }^{14} \mathrm{C}$ Method. Neth J Sea Res 16:362-379

Lindeboom HJ, Sandee AJJ (1989) Production and consumption of tropical seagrass fields in eastern Indonesia measured with bell jars and microelectrodes. Neth J Sea Res 23:181-190 
Liss PS (1973) Processes of gas exchange across an air-water interface. Deep-Sea Res 20:221-238

Liss PS, Slater PG $[1974\}$ Flux of gases across the air-sea interface. Nature 247:181-184

McRoy CP, Helfferich C (1974) Seagrass ecosystems: a scientific perspective. Marcel Dekker, New York

Murray L. Wetzel RL (1987) Oxygen production and consumption associated with the major autotrophic components in two temperate seagrass communities. Mar Ecol Prog Ser 38:231-239

Nixon SW, Oviatt CA (1972) Preliminary measurements of midsummer metabolism in beds of eelgrass, Zostera marina. Ecology 53(1):150-153

Nixon SW, Oviatt CA (1973) Ecology of a New England salt marsh. Ecol Monogr 43:463-498

Odum EP (1971) Fundamentals of ecology. WB Saunders Co, Philadelphia

Odum HT (1956) Primary production in flowing waters. Limnol Oceanogr 1:102-117

Odum HT (1963) Productivity measurements in Texas turtle grass and the effects of dredging an intracoastal channel. Publ Inst Mar Sci Univ Texas 9:48-58

Odum HT, Burkholder PR, Rivero J (1959) Measurements of productivity of turtle grass flats, reefs, and the Bahia Fosforescente of southern Puerto Rico. Publ Inst Mar Sci Univ Texas 6:159-170

Odum HT, Hoskin CM (1958) Comparative studies on the metabolism of marine waters. Publ Inst Mar Sci Univ Texas 5:16-46

Odum HT, Wilson RF (1962) Further studies on reaeration and metabolism of Texas Bays, 1958-1960. Publ Inst Mar Sci Univ Texas 8:23-55

Onuf CP (1996) Biomass patterns in seagrass meadows of the Laguna Madre, Texas. Bull Mar Sei 58(2):404-420

Oviatt CA, Rudnick DT, Keller AA, Sampou PA, Almquist GT (1986) A comparison of system $\left(\mathrm{O}_{2}\right.$ and $\left.\mathrm{CO}_{2}\right)$ and $\mathrm{C}-14$ measurements of metabolism in estuarine mesocosms. Mar Ecol Prog Ser 28:57-67

Park K, Hood DW, Odum HT (1958) Diurnal pH variation in Texas bays, and its application to primary production estimation. Publ Inst Mar Sci Univ Texas 5:47-64.

Patriquin D (1973) Estimation of growth rate, production and age of the marine angiosperm Thalassia testudinum

Editorial responsibility: Otto Kinne (Editor),

Oldendorf/Luhe, Germany
König. Carib J Sci 13:111-123

Peduzzi P, Vukovic A (1990) Primary production of Cymodocea nodosa in the Gulf of Trieste (Northern Adriatic Sea): a comparison of methods. Mar Ecol Prog Ser 64:197-207

Quammen ML, Onuf CP (1993) Laguna Madre: seagrass changes continue decades after salinity reduction. Estuaries 16(2):302-310

Roy RN, Roy LN, Vogel KM, Porter-Moore C, Pearson T, Good CE, Millero FJ, Campbell DM (1993) The dissociation constants of carbonic acid in seawater at salinities 5 to 45 and temperatures 0 to $45^{\circ} \mathrm{C}$. Mar Chem 44:249-267

Schidlowski M (1986) Air pollution. In: Hutzinger $O$ (ed) The handbook of environmental chemistry. Springer-Verlag. Heidelberg, p 158-172

Stumm W, Morgan JJ (1970) Aquatic chemistry: an introduction emphasizing chemical equilibria in natural waters. Wiley-Interscience, New York

Trewartha G (1961) Earth's problem climates. University of Wisconsin Press, Madison, WI

Velimirov B, Walenta-Simon M (1992) Seasonal changes in specific growth rates, production and biomass of a bacterial community in the water column above a Mediterranean seagrass system. Mar Ecol Prog Ser 80: 237-248

Verduin J (1960) Phytoplankton communities of western Lake Erie and the $\mathrm{CO}_{2}$ and $\mathrm{O}_{2}$ changes associated with them. Limnol Oceanogr 5:327-380

Wanninkhof R (1992) Relationship between wind speed and gas exchange over the ocean. J Geophys Res 97(C5): $7373-7382$

Wanninkhof R, Ledwell J, Crusius J (1991) Gas transfer velocities on lakes measured with sulfur hexafluoride. In: Wilhelms SC, Gulliver IS (eds) Air-water mass transfer. American Society of Civil Engineers, New York, p $441-455$

Weiss RF (1974) Carbon dioxide in water and seawater: the solubility of a non-ideal gas. Mar Chem 2:203-215

Wilcoxon $F$ (1945) Individual comparisons by ranking methods. Biometrics 1:80-83

Wilcoxon F (1947) Probability tables for individual comparisons by ranking methods. Biometrics 3:119-122

Zieman JC, Zieman RT (1989) The ecology of the seagrass meadows of the west coast of Florida: a community profile. US Fish Wildl Serv Biol Rep 85(7.25):155

Submitted: December 30, 1997; Accepted: July 13, 1998

Proofs received from author(s): October 19,1998 